\title{
O papel do leitor na obra híbrida Crônica de uma morte anunciada, de Gabriel García Márquez
}

\section{Eliane Galvão Ferreira*}

\begin{abstract}
Resumo: Este texto tem por objetivo apresentar uma possibilidade de leitura da obra Crônica de uma morte anunciada, de Gabriel García Márquez, na qual se considera o papel do leitor e da linguagem, concebida como produção lingüística híbrida, formada pela junção dos discursos literário, jornalístico e forense. Para a consecução do objetivo, pretende-se apresentar uma reflexão fundamentada pela estética da recepção acerca do que propicia o prazer na leitura e de quais elementos determinam o papel do leitor implícito.
\end{abstract}

Palavras-chave: linguagem híbrida; estética da recepção; leitor.

\begin{abstract}
This paper aims to present an opportunity to read the work Chronic of a death foretold, of Gabriel García Márquez, which considers the role of the reader and language, designed as a hybrid language production, formed by the junction of speeches literacy, journalistic and forensic. To achieve the goal, it is intended to present a reasoned reflection by the aesthetics of receipt on what provides the pleasure in reading and what factors determine the role of the reader implied.
\end{abstract}

Keywords: hybrid language; aesthetics of receipt; reader.

\section{Introdução}

Crônica de uma morte anunciada, escrita, em 1981, por Gabriel García Márquez, configura-se sob a forma de um romance que, em linguagem jornalística própria da crônica, busca reconstituir de forma detalhada, por meio do relato em primeira pessoa, o assassinato do personagem Santiago Nasar, de 21 anos. Trata-se de uma narrativa concisa e envolvente, que surpreende o leitor pelo modo como é descrito um crime ocorrido na presença de todos, embora seja, tantas vezes, anunciado, em um pequeno povoado do Caribe colombiano.

A obra de García Márquez insere-se no gênero romanesco de produção contemporânea latino-americana que, assim como os romances pós-modernos, conforme Menton (1993, p.154), permite ampliar os critérios de avaliação crítica dessa produção. Nessas obras, os autores têm como meta principal questionar os conceitos inter-relacionados que se associaram ao humanismo liberal: certeza, autoridade, totalização, continuidade, fechamento, hierarquia e homogeneidade. Nesse processo, García Márquez questiona o próprio fazer ficcional, interpenetrando os discursos jornalístico e jurídico.

\footnotetext{
* Professora Mestra e Doutoranda pela UNESP, campus de Assis. Ministra aulas de língua portuguesa, redação forense e de redação publicitária nos curso de Jornalismo, Direito e Publicidade da FEMA.
} 
Trata-se de um romance que apresenta uma narrativa autoconsciente, que exige tanto o distanciamento, quanto o envolvimento do leitor. Desse modo, apresenta-se como um romance popular que, ao mesmo tempo em que é intensamente auto-reflexivo, de maneira paradoxal, também se apropria de acontecimentos e personagens históricos, misturando ficção a dados biográficos do escritor. O universo do romance de Gabriel García Márquez não se limita, então, ao mundo da ficção, uma vez que se combina com a realidade referencial. O autor narra fatos que, segundo Olga Martínez Dasí (2007, p.6), realmente aconteceram em um povoado onde morou e que envolveram amigos e pessoas de sua família. Justifica-se, então, que essa obra seja considerada, entre os romances de García Márquez, a mais realista.

Para a consecução do objetivo de apresentar uma possibilidade de leitura de Crônica de uma morte anunciada, opta-se neste texto pelo caminho da dialogia, a partir da hipótese de que somente pela leitura plurissignificativa pode-se compreender o diálogo entre textos diversos de diferentes autores, que se instaura no interior da obra e que a define.

\section{Fundamentação Teórica}

Norteia esta análise a concepção, conforme Regina Zilberman (1984, p.133-134), de que uma obra, por ser uma unidade concomitantemente composicional e dialógica, é portadora de um fenômeno literário, que circula do plano ficcional ao ideológico a partir de sua estrutura, independentemente da sociedade que o produz ou que reflete. Para tanto, buscase compreender como se organizam os discursos na narrativa.

De acordo com Cyana Leahy-Dios (2000, p.27), um dos benefícios potenciais da literatura é a ampliação do sentido das múltiplas possibilidades de vida no leitor. Ela lhe dá uma chance de "viver" dilemas morais. Nesse sentido, constrói-se, neste texto, a hipótese de que o contato com o romance pós-moderno permite ao leitor a ampliação de sua visão de mundo, pois ele vê a realidade sob novos prismas, refaz o "real". Isto porque, segundo Diana Luz Pessoa de Barros (1999, p.7), os discursos literários, por serem dotados de ambivalência intertextual interna e por proporcionarem multiplicidade de vozes e de leituras, permitem a substituição da verdade única pelo diálogo de "verdades textuais", contextuais e históricas. Assim, o leitor reconsidera, por meio do diálogo com textos diversos de diferentes autores, a "verdade única" que possui, ou melhor, que lhe transmitiram.

Neste artigo, parte-se do pressuposto de que a literatura é condicionada, primordialmente, tanto em seu caráter artístico, quanto em sua historicidade, pela relação dialógica entre obra e leitor. Essa relação decorre da estrutura do texto, da presença de vazios 
que solicitam do leitor um papel na composição literária: o de organizador e de revitalizador da narrativa. Esse papel só pode ser exercido quando o leitor preenche os vazios do texto, por meio do ato de concretização, em um processo comunicativo, no qual o leitor "recebe" o sentido do texto ao constituí-lo. Estes vazios presentes no texto indicam os locais de entrada do leitor no universo ficcional. Assim, o texto supõe, necessariamente, um recebedor incumbido do preenchimento desses vazios. O texto possui, então, uma estrutura de apelo que invoca a participação de um indivíduo na feitura e no acabamento: é seu leitor implícito (ISER, 1999, p.107). As reflexões sobre esse leitor e sua projeção na obra de Márquez justificam-se, pois, por meio delas, pode-se apreender o processo comunicativo presente na obra. Esse processo merece ser considerado, pois de acordo com Iser (1999, p.10), uma obra só é atraente para o leitor quando lhe permite estabelecer uma comunicação.

\section{A narrativa e suas estratégias de sedução}

O romance de García Márquez se inicia em ultimas rés. Assim, o assassinato já se consumou, e cabe ao leitor acompanhar o narrador que, de forma tensa e gradativa, por meio da interpenetração de testemunhos diversos e desencontrados, narra como e por que Santiago foi morto, em uma segunda-feira de fevereiro, há 27 anos. A estratégia narrativa prende o leitor até o final da leitura. Por meio dela, o narrador afirma que voltara ao abandonado povoado em que vivera, com o objetivo de tentar "recompor, o espelho quebrado da memória" (GARCÍA MÁRQUEZ , 2006, p.13). Entretanto, como o próprio título da obra atesta, a hipótese do narrador incide sobre o fato de que Santiago, seu amigo de infância e de juventude, fora vítima de uma morte muito anunciada no povoado e, ainda, de um critério de honra distorcido. Para o narrador, Santiago se deixara matar ou por que se atordoara com os avisos desencontrados da população, ou por descuido da inocência. Seu relato inicia-se com a abordagem dos sonhos de Santiago, no dia anterior à sua morte, e do caráter de prenúncio deles. Mesmo assim, tanto ele, quanto sua mãe, Plácida Linero, famosa como intérprete de sonhos, os ignoraram. O narrador define de forma objetiva e concisa seu amigo Santiago Nasar: órfão de pai, árabe, herdeiro de uma fazenda, solteiro, noivo e residente de uma bela casa que dividia com sua mãe. Embora sejam sucintas suas descrições, elas não coincidem com as das demais personagens, justamente por isso, permitem ao leitor tanto imaginar Santiago, sua origem social, seus laços de parentesco e seus vínculos com o poder, quanto desconfiar das avaliações subjetivas do narrador em relação ao protagonista. Dessa forma, a 
narrativa convoca o leitor a realizar deduções por si mesmo e a não aderir às opiniões das personagens.

No mesmo dia do assassinato, o povoado agitava-se com a chegada de um navio que traria um bispo para abençoar a população. Santiago não dormira bem na noite anterior, pois, como todos, festejara até tarde o casamento arranjado de Ângela Vicário com o milionário Bayardo San Román. Após o término da festa, prosseguira com a farra, junto de amigos, inclusive do narrador, em um prostíbulo. Desse modo, dormira apenas uma hora antes de se levantar para ir ao porto celebrar a chegada do bispo. Uma hora após a partida do navio, do qual o bispo sequer descera, abençoando a distância o povoado, os irmãos gêmeos Pedro e Pablo Vicário, de 24 anos, perseguiram Santiago e o esfaquearam inúmeras vezes à porta de sua casa, que estava fechada com um ferrolho, porque sua mãe, na tentativa de protegê-lo, imaginando-o em casa, trancara-na. O crime cometido pelos gêmeos deu-se em defesa da honra de sua irmã. Essa performance, aguardada pelo povoado e aceita, socialmente, como justa, ocorreu porque Bayardo, na madrugada do casamento, devolvera Ângela aos pais, alegando que não era virgem. A moça, prima do narrador, após ter sido surrada por sua rigorosa e religiosa mãe, cujo nome reforça sua caracterização, Pura Vicário, confessara aos irmãos o 'autor da desonra': Santiago.

O narrador prossegue seu relato afirmando de forma preconceituosa que essa revelação nunca convencera ele e muitos no povoado, pois Ângela e Santiago pertenciam a mundos diversos. Ele era rico, bem posicionado; ela, inexpressiva e pobre. Assim, supunham que ela acobertava alguém. Entretanto, ao juiz, ela reafirmou a sua versão. A narrativa encaminha-se para seu desfecho, com o narrador viajando e encontrando sua prima 23 anos após o crime, já como moradora de outro povoado, Guajira, abrasado "pelo sol do Caribe, onde sua mãe resolvera enterrá-la em vida” (GARCÍA MÁRQUEZ, 2006, p.130). Nessa ocasião, ele reafirma a pergunta crucial, a que ela responde o mesmo que dissera ao juiz. Mas Ângela relata, então, uma novidade ao narrador, afirma que, após a partida de Bayardo do vilarejo, descobrira que ele era seu verdadeiro amor. Essa constatação confirmou-se quando ela, acompanhando sua mãe ao hospital de Riohacha para um exame de vista, avistou-o sem que ele a percebesse. Após esse encontro, durante 17 anos, lhe enviara cartas de toda espécie: de súplica, de amor, de ofensa etc., implorando que voltasse. Ele voltou, porque também a amava e, finalmente, estavam juntos. Quatro anos depois desse encontro com a prima, o narrador retorna ao vilarejo em que crescera e descreve os tristes destinos de morte, prostituição, solidão, abandono e loucura, reservados a cada morador que, na ocasião, testemunhou, mesmo sem ser chamado para isso, na ânsia de esconder o fato de que poderia 
ter impedido o crime. Em sua defesa, eles argumentavam que ninguém pode interferir quando se trata de crime para defender a honra. O discurso da mãe do narrador, contrário ao consensual no povoado, sintetiza a narrativa, pois ela afirma que: "A honra é o amor" (GARCÍA MÁRQUEZ , 2006, p.144).

O livro possui cinco capítulos que apresentam, de forma equilibrada, a distribuição da narrativa. Esses capítulos completam-se e, pela trama narrativa do suspense, mantém a atenção de quem lê. Embora a obra não possua prefácio que a apresente, a sua abordagem do tema da 'morte anunciada', ou seja, do crime passional, é coerente e atraente para o leitor que estabelece um jogo, por meio da leitura, acompanhando a hipótese do narrador, enquanto preenche os vazios instaurados em busca de pistas que evidenciem a tese. O final é surpreendente, pois revela que o objetivo do personagem narrador não era provar sua hipótese de que a morte já estava prevista e, apesar disso, ninguém fizera nada, era, antes, apaziguar a própria inquietude a respeito do conceito de honra. Essa tranqüilidade só é obtida, quando ele se recorda do discurso de sua mãe que o remete ao fato de que, afinal, Ângela e Bayardo ficaram juntos. Assim, o que importa mesmo é o amor.

A organização geral da obra favorece a leitura, pois seu projeto gráfico editorial é bem-sucedido. Ela apresenta, em seu jogo com o leitor, uma estratégia de manutenção do tom jornalístico e jurídico, e também humorístico, com fins de assegurar a atmosfera de tensão e de contradição entre os discursos das testemunhas oculares:

As muitas pessoas que encontrou [Santiago] desde que saiu de casa às 6 h05 até que foi retalhado como um porco, uma hora depois, lembravam-se dele um pouco sonolento mas de bom humor, e com todos comentou de um modo casual que era um dia muito bonito. Ninguém estava certo se ele se referia ao estado do tempo. Muitos coincidiam na lembrança de que era uma manhã radiante com uma brisa de mar que chegava através dos bananais, (...). A maioria porém, estava de acordo em que era um tempo fúnebre, de céu sombrio e baixo e um denso cheiro de águas paradas, e que no instante da desgraça estava caindo uma chuvinha miúda (...). (GARCÍA MÁRQUEZ, 2006, p.10)

As informações que aparecem no verso da abertura, listando as obras do autor; na capa do livro, onde se lê: "Prêmio Nobel de Literatura"; no verso da folha de rosto, sob a forma de biografia: "mestre do realismo fantástico latino-americano", completam-se e agregam valor simbólico à obra, assegurando as vendas e endossando a competência de Gabriel García Márquez para a produção literária. 


\section{0 jogo com o leitor}

Crônica de uma morte anunciada dialoga com contextos culturais do leitor. Por meio de seu intertexto, instiga-o a estabelecer, na leitura, relações com textos literários diversos que remetem às próprias obras de Márquez, com suas obsessões pela honra e pela morte, aos labirintos de Borges e de Umberto Eco entre outros, inclusive aos textos jurídicos: "O advogado sustentou a tese do homicídio em legítima defesa da honra, admitida pelo tribunal da consciência, e os gêmeos declararam ao final do julgamento que voltariam a fazer mil vezes o que fizeram pelos mesmos motivos" (GARCÍA MÁRQUEZ, 2006, p.73); e jornalísticos: "Poncho Lanao, a esposa e cinco filhos não sabiam de nada do que acabava de ocorrer a 20 passos de sua porta. 'Ouvimos a gritaria', disse-me a mulher, (...)" (GARCÍA MÁRQUEZ, 2006, p.176). Seu jogo discursivo propicia o questionamento ao leitor que, enquanto observa os relatos sobre a tragédia, percebe que a obsessão do narrador sobre o assunto advém de suas angústias relacionadas à questão da honra. Logo, pela abordagem da temática, a obra contribui para o desenvolvimento da percepção de mundo, para a reflexão sobre a realidade, sobre si mesmo e sobre o outro. Pelo emprego do intertexto, da linguagem e do jogo discursivo, ela favorece a ampliação das referências estéticas, culturais e éticas do leitor.

A opção do autor pela técnica discursiva própria da crônica sinaliza para o leitor o anseio do narrador de descrever e recolher tanto suas reminiscências, quanto as das testemunhas oculares do assassinato da forma mais objetiva e racional possível, sendo apassagem do tempo o elemento construtor do enredo, assim percebida desde o início do romance: "No dia em que o matariam, Santiago Nasar levantou-se às 5h30m da manhã (...)" (GARCÍA MÁRQUEZ, 2006, p.9). A objetividade na narrativa vem assinalada pelo emprego sistemático dos horários exatos em que ocorreram as ações relacionadas ao crime. Embora a ênfase na estrutura desse romance recaia na irreversibilidade da passagem do tempo, concebido em sua noção mitológica como devorador, justamente esse transcorrer temporal permite ao leitor observar que há uma série de contradições nos depoimentos referentes ao dia do crime, mais especificamente, quanto ao tempo atmosférico. Nesse caso, a idéia vaga a respeito do tempo sugere a presença da perspectiva dialógica inserida na narrativa, em que diferentes vozes ou percepções se opõem ao descrever o fatídico dia.

Outra característica própria da crônica que aparece é o emprego da linguagem objetiva, concisa e simples nos trechos relativos ao crime, desde sua premeditação até a consumação, episódio no qual o enredo estrutura. O estilo objetivo também aparece em 
diversos episódios que marcam a progressividade do tempo como, por exemplo, quando Cristo Bedoya, amigo de Santiago Nasar, declara ao narrador que, procurando Santiago em sua casa para verificar se ele estava a salvo, vai até seu quarto e observa que o seu relógio esquecido sobre o criado-mudo "marcava 6h58m" (GARCÍA MÁRQUEZ, 2006, p.157). Assim, há na narrativa uma cronologia bem marcada em episódios que, apoiados no tempo cronológico, estruturam-se para que se feche o ciclo do tempo entre a acusação de desonra, a premeditação, a divulgação e o crime.

O livro é atraente, pois mantém, pelo seu jogo discursivo, a atenção do leitor até o final da leitura, ainda, pelo exercício de dedução que o instiga a realizar, convida-o à participação criativa e reflexiva. A obra não busca conduzir a opinião do leitor, também não lhe oferece um comportamento ideal a seguir, antes lhe permite a revisão de valores e de conceitos prévios. Assim, explora recursos expressivos no tratamento dado ao tema e este é relevante para a formação humana. A abordagem do tema é dinâmica, consistente e escapa de simplificações nas representações, também repleta de lacunas que solicitam a interação na leitura. Pode-se deduzir, então, que a preocupação estética centra-se na manutenção da coerência no emprego da linguagem que se revela desautomatizada pela interpenetração de tipos diferentes de discurso: o literário, o jurídico e o jornalístico. Desse modo, o livro propicia uma experiência significativa ao leitor quanto aos usos literários da língua e à configuração discursiva.

A natureza da obra é comunicativa, pois solicita, por meio de lacunas, que o leitor realize a concretude em busca do sentido do que, embora não seja enunciado, está pressuposto. A cena em que o narrador reflete sobre a conduta da maioria das pessoas do povoado exemplifica bem esse aspecto:

Mas a maioria dos que puderam fazer alguma coisa para impedir o crime e, apesar de tudo, não o fizeram, consolou-se com invocar o preconceito de que as questões de honra são lugares sagrados aos quais só os donos do drama têm acesso (GARCÍA MÁRQUEZ, 2006, p.144).

Trata-se de uma obra que estabelece uma paródia com os romances detetivescos, pois logo no primeiro capítulo sabe-se quem são os assassinos de Santiago. O que a identifica com a produção pós-moderna é o fato de que, como romance detetivesco parodístico, recria a vida no povoado latino-americano e os conflitos entre os valores relacionados à honra e à vingança, aproximando-se dos contos de Borges, da obra $O$ nome da rosa, de Umberto Eco, entre outros. O diálogo entre a obra de Márquez e os textos narrativos pós-modernos 
evidencia-se também no uso de várias técnicas de metaficção, da simbologia e da metáfora do labirinto.

\section{O absurdo como força criadora}

A narrativa reconstrói a atmosfera medieval do julgamento público ao qual o povo assiste, organizando-se na praça como para um espetáculo. Desse modo, o assassinato de Santiago ocorre à vista de todos e com o consentimento inclusive das autoridades locais e do representante da Igreja, no caso da religião católica. Pela construção da trama, García Márquez critica impiedosamente os conceitos associados à honra, à virgindade e ao casamento. A obra explora, então, o absurdo como força criadora da literatura, pois produz a indignação que não elimina a reflexão, não paralisa a efervescência de idéias.

Em sua temática, a obra recusa a visão de que o consenso social detém a verdade, por meio da afirmação de que tanto os discursos historicamente situados, quanto a ficção são discursos, construtos humanos, sistemas de significação, e é a partir dessa identidade que obtém sua principal pretensão à verdade. Desse modo, configura-se, também como construto humano, a representação de um processo jurídico e de um julgamento baseado em valores sociais. Questiona-se então na obra os valores socialmente instituídos, às vezes ligados à ingenuidade e à simplicidade de saberes de pessoas simples e humildes, habitantes de pequenos povoados, cujos hábitos e crenças, como o poder do destino, o sentimento de fatalidade, a idéia de desigualdades e o valor da honra, possuem um terreno fértil para se desenvolver. A simplicidade do universo e a rusticidade no modo de vida dos gêmeos Vicário lhes fizeram acreditar que a eles se impunha o dever de lavar a honra da irmã; essa era a sua lei, porque era também a lei do lugar em que viviam: "Naquele momento, reconfortava-os a ilusão de haver cumprido com a sua lei (...)" (GARCÍA MÁRQUEZ, 2006, p.117).

Para Seymour Menton (1993, p.154), o romancista latino-americano se considera muitas vezes a consciência de sua nação, com a responsabilidade de denunciar os abusos e formular uma nova ordem social. Para atingir esse objetivo, García Márquez constrói sua obra, como representação de um crime, sem eleger um único protagonista, antes todo um povoado, permitindo, assim, ao leitor uma reflexão acerca dos culpados pelo crime, se eles seriam apenas os gêmeos Vicário ou como conclui o narrador: todos. A representação na trama de diferentes concepções e visões e a abundância de disfarces projetam uma visão dialógica da realidade, conforme Menton (1993, p.59), em termos borgeanos: o leitor não 
pode decidir quem é o herói e quem é o traidor. No caso da narrativa de Márquez, sequer o narrador é confiável em seus julgamentos.

A representação da mulher na narrativa aparece de forma paradoxal frente a costumes nos quais preponderam valores de um mundo masculino, como é o caso do dever de lavar a honra com sangue. Por meio das personagens femininas, o autor apresenta questionamentos sobre tais conceitos. Desse modo, algumas mulheres mostram-se indignadas com os valores machistas: a mãe do narrador e Clotilde Armenta, dona da leiteria, lugar em que as pessoas do povoado se reuniam. Estas mulheres são detentoras de um poder: organizar a vida familiar e perceber as contradições existentes em um mundo que se mostra masculino. Entretanto, no mesmo povoado há mulheres como Prudência Cotes, noiva de Pablo Vicário, e sua mãe, bem como a matriarca da família Vicário que esperam dos gêmeos uma atitude digna de "homem", ou seja, atitude de vingança.

Também há mulheres pertencentes a classes desprestigiadas que, embora se conformem com seus destinos, ou seja, submeterem-se sexualmente aos caprichos dos homens poderosos, não perdema oportunidade de se vingarem. Como exemplo disso, pode-se notar o comportamento da empregada de Santiago, omitindo-se em dizer-lhe que corre risco de vida. Dessa forma, o povoado representa um espaço primitivo, uma vez que inúmeras passagens demonstram que o conhecimento provém de um processo cognitivo ligado ao empírico, a saberes que nascem de vivências e de experiências cotidianas. Justifica-se que componham esse espaço social as superstições e os sonhos, montando, assim, um quadro de uma visão de mundo mítica com lendas e presságios que se misturam à fé religiosa e a dogmas fundamentados em rituais e em hierarquias.

O tempo na diegese é ulterior, tudo já aconteceu quando está sendo narrado. A narrativa é linear, entretanto o narrador intencionalmente recua e avança a narração para além das performances, para, assim, evidenciar a sua revisão de valores e ampliação de conhecimento de mundo. $\mathrm{Na}$ constituição da obra, prevalece a preocupação com a manutenção do princípio de plausibilidade na organização da trama e na sucessão de eventos associados à morte de Santiago. Assim, o relato se inicia às $5 \mathrm{~h} 30$ da manhã em que Santiago seria morto e prossegue até 7h05 quando finalmente morreu. Alguns elementos do romance, como o assassinato, foram determinados pelo fato histórico, mas outros pertencem exclusivamente ao ficcional, à intenção do autor. Segundo Eco, a "resposta pós-moderna ao moderno consiste em reconhecer que o passado, como não pode ser realmente destruído porque sua destruição conduz ao silêncio, precisa ser reavaliado: mas com ironia, e não com inocência" (ECO, 1985, p.56). 
A obra se apropria do procedimento básico da tragédia, tanto nas imagens, quanto na linguagem e no tema. Entretanto, realiza a contenção da atmosfera trágica por meio da carnavalização, quando há o rebaixamento de tudo que é elevado para o plano material e corporal. Assim, ela faz referência, pelos sonhos de Santiago e pelos símbolos associados a esse personagem, à ambigüidade do mundo, onde tudo aparece com duplo sentido. Como há uma ridicularização dos tipos sociais e políticos, e de alguns costumes, por meio do exagero, a obra se aproxima da tragicomédia de costumes.

Em sua estruturação, o romance explora diversos temas; entretanto, todos eles culminam na reflexão acerca da honra e dos valores socialmente constituídos. Como não se chega à conclusão definitiva alguma, porque as opiniões são diversas, a obra tematiza o vazio. De fato, o único que sobreviveu à tragédia. Esse vazio que começa a ser preenchido, não por uma versão que se opõe à oficial, mas, sim, por muitas versões, ou melhor, por uma versão que vai mudando com o passar do tempo, segundo quem a vê. De acordo com Thomás Eloy Martínez (1996, p.2), para o romancista pós-moderno, escrever não é se opor aos absolutos, mesmo porque eles não se sustentam. Logo, escrever é desvendar a única verdade possível: a de que não há uma verdade única. Desse modo, a obra permite ao leitor refletir sobre o conceito de cultura, enquanto contrato social. Como o romance todo problematiza certezas, a estruturação do discurso narrativo dá-se por meio da tomada de depoimentos. Essa estrutura coloca em evidência os conflitos entre diferentes percepções da realidade, fatos e crenças, verdade e ilusão. A estruturação de uma trama unificada e estruturada em uma narração descentralizada, com seu ponto de vista oscilante e permeado de digressões, permite ao leitor uma ampliação dos seus conceitos de imaginário, de realismo e de história.

\section{A subversão como elemento atraente}

Crônica de uma morte anunciada explora os arquétipos literários, subvertendo os conceitos habituais do leitor. Desse modo, o povoado aparece sem centro nem periferia, representando a imagem do labirinto, que substitui a noção convencionalmente organizada que se costuma ter com relação a esse tipo de localidade. O labirinto como estrutura arquetípica conduz o homem ao interior de si mesmo, ao seu inconsciente. Esse interior só pode ser atingido pela consciência, depois de longos desvios ou de uma intensa concentração, até esta intuição final em que tudo se simplifica por uma espécie de iluminação. Quanto mais difícil a viagem, quanto mais numerosos e árduos os obstáculos, mais o adepto se transforma e, no curso desta iniciação itinerante, adquire um novo ser. Conforme Joseph Campbell (2000, 
p.41-43), a procura é sempre motivada por uma deficiência simbólica, e aquilo que é revelado sempre estivera presente no coração do herói ou do grupo heróico. Assim, a incursão pelo povoado na narrativa, inclusive pelos meandros das reminiscências das personagens, representa o desejo do narrador de obtenção de um saber que lhe conferia a revelação: o poder. Entretanto, esse saber é paradoxal, marcado pela ausência se síntese, ou seja, pela detecção de que não há consenso quanto aos valores e julgamentos sociais.

Outros arquétipos explorados na obra são os da árvore, do pássaro e do número cinco. Todos associados, conforme Chevalier e Gheerbrant (1999) à dualidade expressa entre vida e morte. Entretanto, na narrativa, aparecem não com significado único; antes, móvel, alterado de acordo com cada relato das personagens fornecido ao narrador. Os sonhos recorrentes de Santiago com árvores, interpretados erroneamente como positivos, remetem à proximidade da morte. Contudo, as árvores também fálicas estão associadas ao personagem, evocando seu perfil machista e dominador, percebido por uma das mulheres que sexualmente oprime. $\mathrm{O}$ próprio Santiago ora é descrito por essa mulher como "gavião carniceiro" (GARCÍA MÁRQUEZ, 2006, p.28), ora, quando se sente confuso com a situação à sua volta, é descrito por um dos homens com os quais convive, como um "passarinho molhado" (GARCÍA MÁRQUEZ, 2006, p.168-169). Dessa forma, sua caracterização expressa a dualidade de visões entre homens e mulheres em um povoado tipicamente machista. O número cinco, por sua vez, marca, na narrativa, a quantidade de horas que Ângela ficou em "seu lar de casada" (GARCÍA MÁRQUEZ, 2006, p.128) antes de ser devolvida à família. Também representa, entre os golpes que Santiago recebera, o número dos que poderiam ser considerados fatais. O narrador alerta para o fato de que cinco horas antes do assassinato, Santiago estivera bebendo e festejando com seus algozes, os gêmeos Vicário. Finalmente, o livro de Márquez possui cinco capítulos.

A obra é atraente para o leitor não só pela presença dos arquétipos que estão em seu imaginário, mas também pela presença de elementos próprios da aventura detetivesca, como a morte e o risco, ainda pelos elementos da narrativa cavalheiresca medieval. A morte dá à narrativa de aventura, concomitantemente, uma carga de atração e de repulsão, tanto para a personagem, quanto para o leitor. Na configuração espacial, o risco de morte aparece representado pelas inúmeras passagens de Santiago pelo povoado. $\mathrm{Na}$ obra, a comunicação com o leitor dá-se também no plano discursivo por meio da intertextualidade que substitui o relacionamento entre autor e texto, e entre leitor e texto, situando o locus do sentido textual dentro da história do próprio discurso. A comunicação ocorre ainda por meio da presença de vazios intencionais que geram expectativa e tensão. O suspense explora o medo e o desejo de 
saber do leitor. Assim, o leitor não consegue parar de ler enquanto não vê resolvida a situação em suspenso.

Como romance pós-moderno, a obra procura oferecer uma apresentação literária dialética que perturba os leitores, forçando-os a examinar seus próprios valores e crenças, em vez de satisfazê-los ou mostrar-lhes complacência. A obra objetiva produzir, pela intriga, tensão, diversão e questionamento. Para a consecução desse objetivo, opta pela paródia que funciona para distanciar e, ao mesmo tempo, envolver o leitor numa atividade hermenêutica de participação. Por meio dessa atividade, o passado é apresentado criticamente na obra em relação com o presente. As questões referentes à sexualidade, desigualdade, responsabilidade social, ciência, religião, e relação da honra com a vingança, são todas levantadas e dirigidas ao leitor moderno e às convenções sociais e literárias do contexto histórico da obra. Pode-se observar que, em sua relação com o leitor, o romance contemporâneo não é ideológico, não procura, por meio do veículo da ficção, persuadir seu leitor quanto à correção de uma forma específica de interpretar o mundo. Antes, faz com que seu leitor questione suas próprias interpretações e, por implicação, as interpretações dos outros, apresentando-lhe pela polifonia inúmeros discursos.

\section{$7 \mathrm{O}$ discurso dialógico}

Quanto ao discurso, a obra contém no mínimo três grandes registros: o históricoliterário, o teológico-filosófico e o popular-cultural, equiparando assim as três áreas em que se situam as obras do próprio autor. Todos eles são marcados pela ironia e pelo jogo; entretanto, essas características não implicam, necessariamente, a exclusão da seriedade e do objetivo. $\mathrm{O}$ discurso na obra, caracterizado pela ambigüidade e pela ironia, envolve o leitor que o está decodificando no processo de geração de sentidos, por intermédio da ambigüidade e da polissemia. Ainda, esse discurso é marcado pelo paradoxo, pois está fundado sobre a contradição que atua no sentido de subverter os discursos dominantes, mas depende deles para sua própria existência física: "aquilo que já foi dito". Assim, o discurso se caracteriza pelo repensar sobre o valor da honra e da vingança, da vida e da morte, do certo e do errado, da multiplicidade e do provisório, retomando o símbolo da árvore, do pássaro e do número cinco.

Todos os elementos temáticos, religião, lei, julgamento, fé, saber e poder são questionados de forma ambivalente com questionamentos contemporâneos que demonstram conhecimento teórico do autor e com questionamentos que seguem a linha de raciocínio medieval. O que a obra faz explicitamente é lançar dúvidas sobre a própria possibilidade de 
qualquer sólida "garantia de sentido", qualquer que seja sua localização no discurso, realiza então a própria metalinguagem, por meio de dois movimentos simultâneos, reinsere os contextos da peça processual, como a tomada de depoimentos, a confissão dos irmãos Vicário, a sentença do juiz, como sendo significantes, e até determinantes, mas, ao fazê-lo, problematiza toda a noção de conhecimento jurídico, de justiça e de lei. Para tanto, utiliza-se da objetividade e precisão do discurso jornalístico, enquanto o desautoriza pelo emprego da ironia, da preterição e das hipérboles com fins humorísticos e críticos. O discurso apresentase, desse modo, como antropofágico: desafia os discursos dos quais se apropria, ao mesmo tempo em que aproveita deles tudo o que é significativo. Existe, então, na obra, uma deliberada contaminação do processo jurídico pelos elementos discursivos situacionais, contestando, assim, os pressupostos implícitos das afirmações jurídicas: objetividade, neutralidade, impessoalidade e transparência da representação. Quanto à referência presente no discurso do romance, ela atua no sentido de demolir o que os críticos gostam de denominar “falácia referencial”. Segundo Eco (1985), há negação e afirmação da referência, ou seja, deseja-se o próprio referente histórico ao mesmo tempo em que se quer eliminá-lo.

O narrador configura-se como homodiegético, de primeiro nível, de acordo com Gérard Genette (196-?). Esse narrador aproxima-se de um jornalista. Assim, ele se apresenta como o que retoma os depoimentos mesmo que, às vezes, discorde deles ou não os compreenda. Na obra, ele assume uma postura também dúbia, pois, embora reveja alguns de seus conceitos, outros lhe escapam completamente. Dessa forma, ao narrador não são conferidas a onisciência, nem a onipresença da terceira pessoa. Ainda, o seu ponto de vista é declaradamente limitado, provisório e pessoal.

Como o narrador não é o conhecedor transcendental e controlador, ele relativiza seu lugar no relato, cedendo espaço a outros narradores tão autorizados quanto ele pela narrativa. O discurso desse narrador caracteriza-se pelo paradoxo, pela preterição e pela hipérbole. Desse modo, ele nega no discurso o que na verdade se afirma no enunciado. $\mathrm{O}$ discurso do narrador enfraquece os pressupostos ideológicos que estão por trás daquilo que tem sido aceito como universal e trans-histórico em nossa cultura: a noção humanista do Homem como um sujeito coerente e contínuo. O narrador, enquanto personagem, caracteriza-se por comportamentos paradoxais: muitas vezes, entra em conflito com o que as pessoas do povoado acreditam, desejando ser o traidor; outras, com o que as mulheres pensam a respeito de Santiago. Contudo, o narrador, ao apresentar na história o que conhece e buscar nos depoimentos de outras personagens os elementos que desconhece, deixa claro que também não lhe foi permitido saber tudo, que há segredos não revelados e que o conhecimento destes 
pertence somente à personagem Ângela. A posição do narrador é estratégica na narrativa, pois corrobora com a intenção do autor de jogar com as incertezas, construindo-as através da multiplicidade de pontos de vista, ou seja, das intervisões de personagens, segundo Marileda Inês de Borba (2007, p.74).

A relativização do papel do narrador que confere voz às demais personagens na reconstituição da história é uma característica basilar da perspectiva dialógica do texto. Assim, a obra não apresenta uma postura ideológica única e autoritária, qual seja a oposição entre o certo e o errado. Em síntese, o próprio romance questiona os fatores que conduzem à idéia de certo e de errado, e isso se mostra através da intriga criada a partir do tema de um crime em defesa da honra e na apresentação das diferentes percepções das personagens sobre os fatos. Pode-se concluir, então, que o autor explora a idéia de que alguns costumes, crenças, preconceitos e o individualismo podem prevalecer, muitas vezes, sobre sentimentos como solidariedade, amor, entre outros, e que, dessa forma, confundem criando uma inversão de valores a ponto de se tornarem mais relevantes ao homem do que sua própria vida.

\section{Entre ficção e história}

$\mathrm{Na}$ obra, a eleição das personagens expressa a dialogia entre ficção e história. Assim, algumas são criações do autor; outras, figuras históricas e outras, próprias de lendas e crônicas medievais. Mesmo as que encontram referentes históricos, caracterizam-se por serem míticas, definidas de forma incompleta ou obscura pela história e, justamente por isso, atraentes para o leitor. É o caso de Santiago que, embora tenha nome diverso ao do amigo de García Márquez, Cayetano Gentile Chimento, jovem vítima de assassinato em sua própria porta, em Sucre, pelos irmãos de uma antiga e ressentida namorada, por ter desrespeitado "suas prendas virginais" (apud FUKS, 2007, p.29-31), possui destino semelhante; da mãe do narrador com nome homônimo ao da mãe de García Márquez; do pedido de casamento que o narrador fizera na festa de Ângela à jovem personagem Mercedes Barcha de nome homônimo ao da esposa de García Márquez. Há, ainda, outras referências intertextuais a elementos lendários, como à lenda de Isolda e do rei Marcos na eminência de descobrir na noite de núpcias que a jovem não era virgem, tratando da problemática de valores culturalmente aceitos. Dessa forma, os questionamentos sobre como a cultura representa o sujeito, como esse sujeito faz parte dos processos sociais de diferenciação, exclusão, incorporação e regra, que fazem da representação o ato de fundamentação da cultura, são dirigidos ao leitor. Desse modo, mesmo na composição das personagens, a obra caracteriza-se pelo diálogo intertextual, que Barthes 
definiu como intertexto, ou seja, como a "impossibilidade de viver fora do texto infinito", fazendo da intertextualidade a própria condição da textualidade (apud HUTCHEON, 1991, p.167). A obra estabelece, então, diálogos com textos de Borges, do próprio Márquez, de Eco e outros, e com as histórias presentes nas crônicas medievais e nos testemunhos dados em juízo.

No plano da linguagem, pode-se observar o recurso aos elementos estilísticos, tais como a metáfora, a metonímia, a hipérbole, a ironia e a preterição. Há também a estilização oral e o aproveitamento de provérbios e de casos. A linguagem caracteriza-se pela representação plástica na constituição de cenas, conferindo ao leitor, por meio de metáforas e de sinestesias, suspense e possibilidade de visualização dos cenários. Muitas das descrições plásticas das ações das personagens, como na cena em que o narrador recolhe pedaços do processo no alagado Palácio da Justiça de Riohacha, 20 anos depois do crime, remetem a um intertexto:

Eu mesmo procurei, muitas vezes com água até os tornozelos, naquele tanque de causas perdidas, e só um acaso me permitiu resgatar, depois de cinco anos de buscas, umas 322 folhas salteadas das mais de 500 que devia ter o sumário (GARCÍA MÁRQUEZ, 2006, p.146).

No caso dessa cena, há uma referência à paródia intertextual da metaficção historiográfica: embora o passado exista, este só pode ser conhecido de forma limitada e fragmentária, a partir de seus textos, de seus vestígios, sejam literários ou históricos. Os recursos estilísticos e metaficcionais na obra permitem que ela se torne polissêmica, atingindo o efeito poético, a começar pelo próprio título. Assim, a obra permite leituras sempre diversas, sem nunca se esgotar completamente. Justifica-se, então, o objetivo desse artigo em apresentar uma dessas possibilidades de leitura.

Pode-se concluir, portanto, que a obra se define pela mistura entre o auto-reflexivo e o ideológico, permitindo uma fusão daquilo que se costuma manter separado no pensamento humanista. Crônica de uma morte anunciada ensina que a linguagem pode ter muitos usos e abusos. Conforme se representa na obra, as coisas importantes estão além das palavras, mas ainda são intensamente reais, e até mais reais por não serem articuladas ou nomeadas.

Os paradoxos pós-modernos revelam e questionam as normas predominantes, e podem fazê-lo porque encarnam os dois processos. Eles ensinam, de acordo com Hutcheon (1991, p.289), que a representação não pode ser evitada, mas pode ser estudada a fim de demonstrar como legitima certos tipos de conhecimento e, portanto, de poder. Assim, confirma-se a 
hipótese inicial deste artigo de que o leitor, ao ler o romance pós-moderno, pode rever seus conceitos prévios e por conseqüência ampliar sua visão de mundo.

\section{Referências}

BARROS, Diana Pessoa de. Dialogismo, polifonia e enunciação. In: ; FIORIN, José Luiz (Orgs.). Dialogismo, polifonia, intertextualidade: em torno de Bakthin. São Paulo: Editora da Universidade de São Paulo, 1999, p.1-9.

BORBA, Marileda Inês de. $O$ crime em defesa da honra e a narrativa literária: um entrecruzar de caminhos da literatura e do pensamento jurídico. 2007. Dissertação (Mestrado em Letras) - Universidade de Santa Cruz do Sul - UNISC, Santa Cruz do Sul, 2007.

CAMPBELL, Joseph. O herói de mil faces. Trad. Adail U. Sobral. 6.ed. São Paulo: Cultrix, 2000.

CHEVALIER, Jean; GHEERBRANT, Alain. Dicionário de símbolos: mitos, costumes, gestos, formas, figuras, cores, números. Colab. de André Barault et al., coord. Carlos Sussekind, trad. Vera da Costa e Silva et al. 14.ed. Rio de Janeiro: José Olympio, 1999.

ECO, Umberto. Pós-escrito a O Nome da Rosa: as origens e o processo de criação do livro mais vendido em 1984. Trad. Letizia Zini Antunes e Álvaro Lorencini. 2.ed. Rio de Janeiro: Nova Fronteira, 1985.

FUKS, Julián. "Crônica de uma vida habitada". IN: Revista entre livros. v.1, p.24-31, fev. 2007.

GARCÍA MÁRQUEZ, Gabriel. Crônica de uma morte anunciada. Trad. Remy Gorga Filho. São Paulo: Record, 2006.

GENETTE, Gérard. Discurso da narrativa. Trad. Fernando Cabral Martins. Lisboa: Vega, [196-?].

HUTCHEON, Linda. Poética do pós-moderno: história, teoria, ficção. Trad. Ricardo Cruz. Rio de Janeiro: Imago, 1991.

ISER, Wolfgang. $O$ ato da leitura: uma teoria do efeito estético. Trad. Johannes Kretschmer. São Paulo: Ed. 34, 1999. vol.2.

LEAHY-DIOS, Cyana. Educação literária como metáfora social: desvios e rumos. Niterói: EdUFF, 2000.

MARTÍNEZ, Eloy Thomás. Ficção e história: apostas contra o futuro. O Estado de São Paulo, 05 out. 1996, p.D 10-11. 
MARTÍNEZ DASÍ, Olga. Gabriel García Márquez apunte biográfico. Disponível em: <http://sololiteraturaliteraturahispanoamericana.com/php/autor>. Acesso em: $28 \mathrm{dez}$. 2007, p.1-8.

MENTON, Seymour. La nueva Novela Histórica de La América Latina: 1979-1992. México: Colección Popular, 1993.

ZILBERMAN, Regina. A literatura infantil e o leitor. In: ; MAGALHÃES, Ligia Cadermatori. Literatura infantil: autoritarismo e emancipação. 2.ed. São Paulo: Ática, 1984, p.61-134. 